\title{
Analisis Pemanfaatan Jalur Pedestrian pada Kawasan CBD Kota Makassar
}

\author{
Rohana $^{1)}$, Nurlita Pertiwi' ${ }^{2}$, Muzaki ${ }^{3)}$ \\ 1) Arsitektur, Universitas Muhammadiyah Makassar \\ ${ }^{2)}$ Universitas Negeri Makassar \\ ${ }^{3)}$ Manajemen Informatika, STMIK Handayani \\ Email: rohana@unismuh.ac.id
}

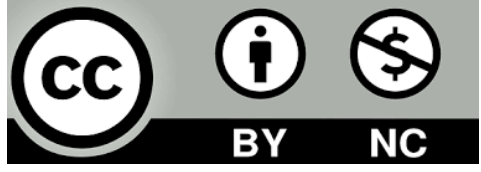

(C) 2020 - UEJ Program Studi Pendidikan Kependudukan dan Lingkungan Hidup Universitas Negeri Makassar. Ini adalah artikel dengan akses terbuka dibawah Licensi CC BY-NC-4.0(http:/creativecommons.org/licenses/by-nc/4.0)

\begin{abstract}
.
Many phenomena arise in the city, which boils down to the problem of pedestrian pathways that are ineffective and neglected to use them. The first: Knowing the factors that cause pedestrian paths do not use well, Secondly: Find the formulation of the model of application of environmental based walkability in accordance with the rules per city design. The location of the research is Jalan Sultan Hasanuddin to Jalan Pattimura and Jalan Slamet Riyadi which are integrated with the CBD (Central Business District) area with a research method combining qualitative and quantitative benefits. The research variables are physical comfort, spatial-visual comfort and non-physical comfort. The analysis was conducted with descriptive, discussion analysis and simple regression based on the significance value of the trial $(\alpha)=0.05$. The results showed that physical comfort variable $\left(X_{1}\right)$ simultaneously had a strong relationship to comfort level $(Y)$, whereas spatial-visual comfort $\left(X_{2}\right)$, and non-physical comfort $\left(X_{3}\right)$ had a weak relationship to comfort level. One of the factors that influence the comfort of the pedestrian path in the area of Sultan Hasanuddin Street - Pattimura Street - Slamet Riyadi Street is the aspect of physical comfort. For the formulation of a Walkability-based environmental concept, in general, namely The provision of pedestrian paths must connect, The need for coordination with related parties regarding the provision of pedestrian paths, Coordination of each party regarding the provision of supporting facilities.
\end{abstract}

Keyword: Pedestrian; Convenience; Walkability; Makassar

\begin{abstract}
Abstrak.
Banyak fenomena masalah lingkungan muncul di kota, yang bermuara pada masalah pemanfaatan jalur pedestrian yang tidak efektif dan terabaikan keberadaannya. Sehingga penelitian ini bertujuan pertama: Mengetahui faktorfaktor yang menyebabkan jalur pedestrian tidak berfungsi dengan baik, yang kedua: Menemukan rumusan model penerapan walkability berbasis lingkungan sesuai dengan kaidah-kaidah perancangan kota. Lokasi penelitiannya Jalan Sultan Hasanuddin mengarah ke Jalan Pattimura dan Jalan Slamet Riyadi yang terintegrasi dengan Kawasan CBD (Central Business District) dengan metode penelitian memadukan pendekatan kualitatif dan kuantitatif. Variabel penelitiannya yaitu kenyamanan fisik, kenyaman spasial-visual dan kenyamanan non-fisik. Analisis dilakukan dengan deskriptif, analisis korelasi dan regresi sederhana berdasarkan nilai signifikansi uji korelasi $(\alpha)=0,05$. Hasil penelitian menunjukkan, variabel kenyamanan fisik $\left(\mathrm{X}_{1}\right)$ secara simultan memiliki
\end{abstract}


hubungan yang kuat terhadap tingkat kenyamanan $(\mathrm{Y})$, sedangkan kenyamanan spasial-visual $\left(\mathrm{X}_{2}\right)$, dan kenyamanan non-fisik $\left(\mathrm{X}_{3}\right)$ memiliki hubungan yang lemah terhadap tingkat kenyamanan. Sehingga hasil penelitian disimpulkan, salah satu faktor yang mempengaruhi kenyamanan jalur pedestrian pada area Jalan Sultan Hasanuddin - Jalan Pattimura - Jalan Slamet Riyadi adalah aspek kenyamanan fisik. Untuk konsep penerapan Walkability yang berbasis lingkungan, secara general yaitu: Penyediaan jalur pedestrian harus bersifat connecting, Perlunya koordinasi ke pihak terkait tentang penyediaan jalur pedestrian, Koordinasi masing-masing pihak tentang penyediaan sarana penunjang.

Kata Kunci: Pejalan kaki; Kenyamanan; Walkability; Makassar.

\section{Pendahuluan}

Jalur Pedestrian merupakan salah satu elemen penting dalam terbentuknya sebuah kota. Kota yang baik adalah kota yang harus memberikan kemudahan terhadap berbagai jenis lalu lintas, baik itu lalu lintas pedestrian maupun lalu lintas kendaraan. Namun kenyataan tersebut tidak sesuai dengan kondisi saat ini, penyediaan jalur lalu lintas kendaraan lebih besar daripada jalur pedestrian, dan ini merupakan fenomena yang menimbulkan beberapa spekulasi dalam sebuah tatanan perancangan kota.

Secara empiris, banyak fenomena masalah lingkungan muncul di kota-kota yang bermuara pada masalah penggunaan jalur pedestrian yang tidak efektif dan terkesan terabaikan keberadaannya. Secara struktural, jalur pedestrian dapat menjadi parameter bagi peningkatan kesejahteraan dan keramahan suatu kota, yang tentunya berhubungan erat dengan inflasi sosial ekonomi sebagai tindak lanjut peningkatan laju pertumbuhan roda pemerintahan.

Salah satu permasalahan yang terlihat di kota Makassar yaitu mengenai pemanfaatan jalur pedestrian yang tidak berfungsi dengan baik, bisa dilihat diberbagai titik penyediaan terutama di pertigaan antara Jalan Sultan Hasanuddin - Jalan Pattimura - Jalan Slamet Riyadi yang terintegrasi dengan kawasan CBD (Central Business District). Jalur tersebut tidak tertata dengan baik dan tidak connecting satu sama lainnya.

Oleh karena jalur tersebut merupakan salah satu elemen dari sistem transportasi perkotaan sebagai prasarana untuk moda berjalan, maka jalur pedestrian perlu direncanakan dengan baik dan berkelanjutan yang berbasis lingkungan, sehingga dapat menjawab kebutuhan penggunanya. Ada tiga aspek yang harus dimiliki dari penyediaan jalur pedestrian sebagai pilihan utama dalam perjalanan jarak pendek, yakni keamanan (safety), keselamatan (security), kenyamanan (convenience) bagi para penggunanya (Krambeck, 2006).

Tujuan penelitian yaitu untuk mengetahui faktor-faktor yang menyebabkan jalur pedestrian tidak berfungsi dengan baik, menemukan model penerapan walkability berbasis lingkungan yang terintegrasi dengan Kawasan CBD kota Makassar yang sesuai dengan kaidahkaidah perancangan kota.

Penelitian ini diharapkan, berguna bagi perkembangan ilmu pengetahuan serta berguna bagi peningkatan kualitas hidup masyarakat diperkotaan pada umumnya dan secara khusus peningkatan kualitas masyarakat kota Makassar, dan juga sebagai bahan masukan bagi Menteri Negara Lingkungan Hidup dalam menyusun kebijakan baru tentang lingkungan, khususnya lingkungan perkotaan yang didalammya terkait jalur pedestrian yang mempunyai unsur pendidikan lingkungan. 


\section{Rohana, Analisis Pemanfaatan Jalur Pedestrian}

\section{Metode}

Jenis penelitian ini adalah penelitian lapangan (field research) dengan menggunakan metode campuran (mixed methodology), yang memadukan pendekatan kualitatif dan kuantitatif dalam hal metodologi (seperti dalam tahap pengumpulan data), dan kajian model campuran memadukan dua pendekatan dalam semua tahapan proses penelitian (Arikunto, 2010). Pengumpulan data dilakukan dengan teknik studi pustaka, dokumentasi, pengamatan/wawancara langsung kepada pengunjung dan pengukuran secara fisik, spasialvisual, dan non-fisik pada titik ukurnya yang berdasarkan adanya unsur elemen-elemen kota pada kawasan tersebut.

Data yang terkumpul, di analisis dengan melakukan klasifikasi awal dan dideskripsikan berdasarkan data faktual. Untuk mengetahui elemen arsitektur yang berhubungan erat secara signifikan, digunakan analisa korelasi dan regresi sederhana yang merupakan salah satu alat analisis kuantitatif untuk menjelaskan hubungan atau pengaruh antar variabel (Sugiyono, 2003). Setelah di dapatkan hasilnya kemudian digunakan untuk merumuskan konsep penerapan Walkability.

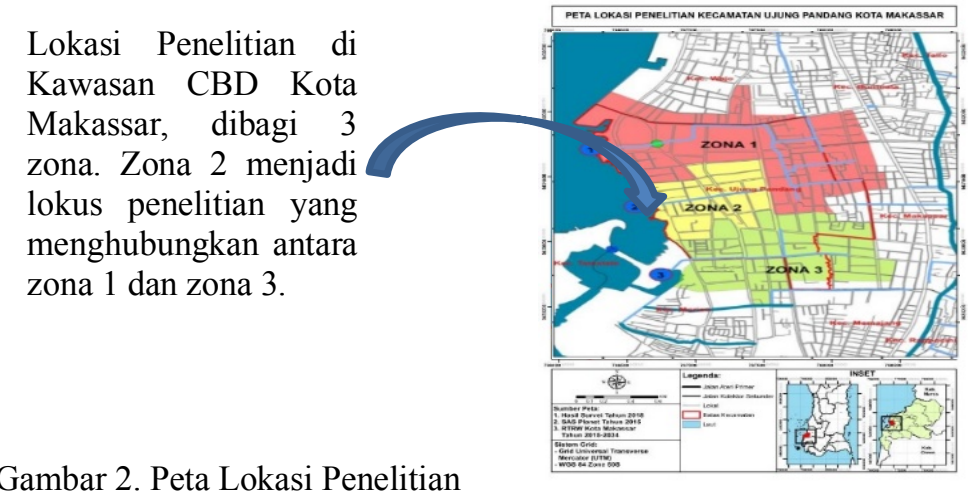

Gambar 2. Peta Lokasi Penelitian

\section{Hasil dan Pembahsan}

\section{Hasil}

Pergerakan pejalan kaki yang memakai jalur pedestrian dari satu titik ketempat lain yang memanfaatkan jalur pedestrian di kawasan tersebut sering menggunakan tepi badan jalan sebagai jalur untuk pedestriannya. Hal ini disebabkan bahwa jalur pedestrian seharusnya nyaman untuk pejalan kaki yang menuju ke suatu titik tujuan. Untuk lebih jelasnya dapat dilihat dari beberapa dokumentasi data penelitian: 

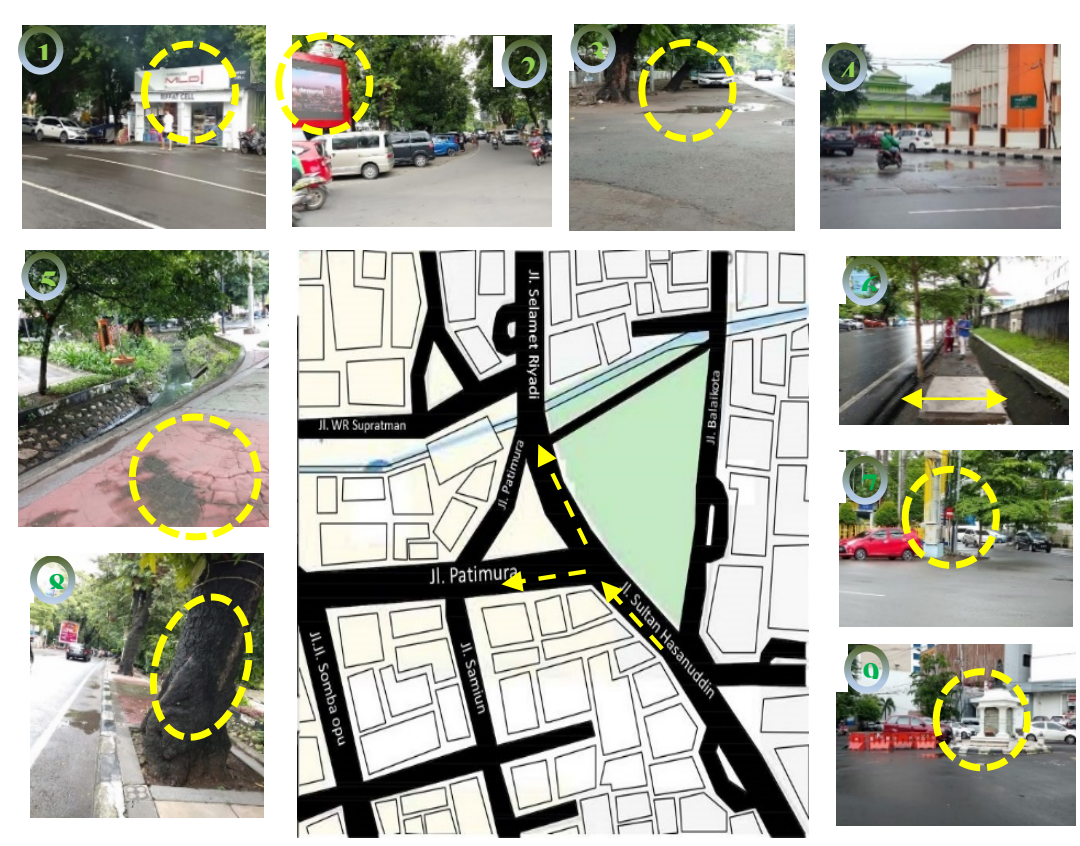

Gambar 2. Situasi Jalur Pedestrian Sumber: Dokumentasi Peneliti 2020 $\underline{\text { Data Penelitian }}$

Entrance

Signage

Street Furniture

Continuitas

Material permukaan

(6) Lebar Jalur

(7) Kondisi Lalu lintas

(8) Vegetasi

(9) Keamanan

\section{Kenyamanan menurut Persepsi Responden}

Tingkat kenyamanan menurut responden dibagi atas 3 variabel yaitu: 1) kenyamanan fisik dengan 6 indikator yang hasil keseluruhan responden menjawab kurang nyaman (43\% lebar ruang pedestrian, 25\% tinggi permukaan, 26\% material permukaan, $32 \%$ continuitas, $43 \%$ street furniture, $30 \%$ vegetasi), 2) kenyamanan spasial-visual dengan 6 indikator, yang mendapatkan respon kurang nyaman (kanopi bangunan 23\%, penanda/signage 30\% dan tinggi bangunan 38\%) dan respon cukup nyaman ( $15 \%$ entrance bangunan, $20 \%$ jarak muka bangunan), dan 3 ) kenyamanan non-fisik diukur berdasarkan 4 indikator, yang mendapatkan respon kurang nyaman (37\% keamanan, 21\% keberadaan PKL dan 20\% kondisi lalu lintas) dan 39\% respon nyaman untuk indikator panas dan hujan.

\section{Kenyamanan menurut Peneliti}

Tingkat kenyamanan jalur pedestrian yang berbeda dengan jawaban responden pada setiap variabel, yaitu: 1) kenyamanan fisik: cukup nyaman (skor 3) pada indikator tinggi permukaan dan material permukaan, rata-rata skor 2 (kurang nyaman) pada indikator lebar jalur pedestrian, dan tidak nyaman dengan rata-rata skor 1 untuk indikator continuitas, street furniture serta vegetasi, 2), variabel kenyamanan spasial-visual: di dapatkan skor rata-rata 2 (kurang nyaman) pada indikator entrance bangunan, penanda/signage, tinggi bangunan, 3) kenyamanan non fisik skor: 3 (cukup nyaman) untuk keamanan, panas dan hujan, skor 2 (kurang nyaman) untuk keberadaan PKL dan kondisi lalu lintas. 


\section{Rohana, Analisis Pemanfaatan Jalur Pedestrian}

Tabel 1. Rangkuman Pendapat Responden dan Peneliti

\begin{tabular}{c|l|c|c|c}
\hline \multirow{2}{*}{ Variabel } & \multirow{2}{*}{ Tabel } & \multicolumn{2}{|c|}{ Skor penilaian } & \multirow{2}{*}{ Keterangan } \\
\cline { 2 - 5 } & Indikator & Responden & Peneliti & \\
\hline \multirow{4}{*}{$\begin{array}{c}\text { Kenyamanan } \\
\text { Fisik }\end{array}$} & Lebar jalur pedestrian & 2 & 3 & Beda \\
\cline { 2 - 5 } & Tinggi permukaan & 2 & 3 & Beda \\
\cline { 2 - 5 } & Material permukaan & 2 & 2 & Sama \\
\cline { 2 - 5 } & Continuitas & 2 & 2 & Sama \\
\cline { 2 - 5 } & Street Furniture & 2 & 2 & Sama \\
\cline { 2 - 5 } & Vegetasi & 2 & 2 & Sama \\
\hline \multirow{2}{*}{$\begin{array}{c}\text { Kenyamanan } \\
\text { Spasial-Visual }\end{array}$} & Entrance bangunan & 3 & 2 & Beda \\
\cline { 2 - 5 } & Signage/penanda & 2 & 2 & Sama \\
\cline { 2 - 5 } & Tinggi bangunan & 2 & 2 & Sama \\
\hline \multirow{3}{*}{$\begin{array}{c}\text { Kenyamanan } \\
\text { Non Fisik }\end{array}$} & Keamanan & 2 & 2 & Sama \\
\cline { 2 - 5 } & Panas dan hujan & 4 & 3 & Beda \\
\cline { 2 - 5 } & Keberadaan PKL & 2 & 2 & Sama \\
\cline { 2 - 5 } & Kondisi Lalu lintas & 2 & 2 & Sama \\
\hline
\end{tabular}

Keterangan :

Skor : (4) Nyaman, (3) Cukup nyaman, (2) Kurang nyaman, (1) Tidak nyaman/buruk

\section{Analisis Uji Korelasi dan Regresi Sederhana}

1. Interpretasi kenyamanan fisik $\left(\mathrm{X}_{1}\right)$

Pada setiap indikator diantaranya: korelasi positif yang terkait dengan tingkat kenyamanan sebanyak 3 indikator dan korelasi negatif sebanyak 3 indikator. Dan hasil output kenyamanan fisik menunjukkan bahwa, ada beberapa indikator yang saling berhubungan terhadap tingkat kenyamanan jalur pedestrian. Hal ini dikarenakan tingkat Sig-nya lebih kecil dari $(0,05)$. Dan ada juga yang tidak berhubungan karena tingkat Sig-nya lebih besar dari $(0,05)$. Sehingga dari hasil analisis disimpulkan bahwa lebar ruang pedestrian dan continuitas terdapat hubungan positif terhadap tingkat kenyamanan, sedangkan tinggi permukaan, material permukaan, street furniture dan vegetasi tidak terdapat hubungan positif terhadap tingkat kenyamanan jalur pedestrian pada kawasan CBD Kota Makassar.

Tabel 2. Hasil uji regresi sederhana kenyamanan fisik $\left(\mathrm{X}_{1}\right)$

\begin{tabular}{r|r|r|r|r|r|r|r|r|r}
\hline Model & R & R Square & $\begin{array}{c}\text { Adjusted R } \\
\text { Square }\end{array}$ & $\begin{array}{c}\text { Std. Error of } \\
\text { the Estimate }\end{array}$ & $\begin{array}{c}\text { R Square } \\
\text { Change }\end{array}$ & F Change & df1 & df2 & $\begin{array}{c}\text { Sig. F } \\
\text { Change }\end{array}$ \\
\hline 1 & $.853^{3}$ & .728 & .704 & .468 & .728 & 30.388 & 6 & 68 & .000 \\
\hline
\end{tabular}


Tabel 3. Hasil uji korelasi kenyamanan fisik $\left(\mathrm{X}_{1}\right)$

\begin{tabular}{|c|c|c|c|c|c|c|c|c|}
\hline \multicolumn{9}{|c|}{ Correlations } \\
\hline & & $\mathrm{Y}$ & $\mathrm{X} 1.1$ & $\mathrm{X} 1.2$ & $\mathrm{X} 1.3$ & $\mathrm{X} 1.4$ & $\mathrm{X} 1.5$ & $\mathrm{X} 1.6$ \\
\hline \multirow[t]{7}{*}{ Pearson Correlation } & $\mathrm{Y}$ & 1.000 & .844 & .107 & .002 & -.217 & -.070 & -.005 \\
\hline & $\mathrm{X} 1.1$ & .844 & 1.000 & .112 & -.100 & -.150 & -.034 & -.067 \\
\hline & $\mathrm{X} 1.2$ & .107 & .112 & 1.000 & -.060 & -.067 & .158 & -.020 \\
\hline & $\mathrm{X} 1.3$ & .002 & -.100 & -.060 & 1.000 & -.063 & -.055 & .163 \\
\hline & $\mathrm{X} 1.4$ & -.217 & -.150 & -.067 & -.063 & 1.000 & .158 & -.046 \\
\hline & $\mathrm{X} 1.5$ & -.070 & -.034 & .158 & -.055 & .158 & 1.000 & -.094 \\
\hline & $\mathrm{X} 1.6$ & -.005 & -.067 & -.020 & .163 & -.046 & -.094 & 1.000 \\
\hline \multirow[t]{7}{*}{ Sig. (1-tailed) } & $\mathrm{Y}$ & & .000 & .180 & .494 & .031 & .276 & .482 \\
\hline & $\mathrm{X} 1.1$ & .000 & & .168 & .198 & .100 & .387 & .284 \\
\hline & $\mathrm{X} 1.2$ & .180 & .168 & & .306 & .283 & .088 & .432 \\
\hline & $\mathrm{X} 1.3$ & .494 & .198 & .306 & & .294 & .319 & .081 \\
\hline & $\mathrm{X} 1.4$ & .031 & .100 & .283 & .294 & & .088 & .348 \\
\hline & $\mathrm{X} 1.5$ & .276 & .387 & .088 & .319 & .088 & & .211 \\
\hline & $\mathrm{X} 1.6$ & .482 & .284 & .432 & .081 & .348 & .211 & \\
\hline \multirow[t]{7}{*}{$\mathrm{N}$} & $\mathrm{Y}$ & 75 & 75 & 75 & 75 & 75 & 75 & 75 \\
\hline & $\mathrm{X} 1.1$ & 75 & 75 & 75 & 75 & 75 & 75 & 75 \\
\hline & $\mathrm{X} 1.2$ & 75 & 75 & 75 & 75 & 75 & 75 & 75 \\
\hline & $\mathrm{X} 1.3$ & 75 & 75 & 75 & 75 & 75 & 75 & 75 \\
\hline & $\mathrm{X} 1.4$ & 75 & 75 & 75 & 75 & 75 & 75 & 75 \\
\hline & $\mathrm{X} 1.5$ & 75 & 75 & 75 & 75 & 75 & 75 & 75 \\
\hline & $\mathrm{X} 1.6$ & 75 & 75 & 75 & 75 & 75 & 75 & 75 \\
\hline$x_{1-1}$ & $=$ Lebe & & destrian & $X_{1.4}$ & $=c$ & intinuite & & \\
\hline$x_{1 \cdot 2}$ & $=$ Ting & rmuke & & $x_{1.5}$ & $=S t$ & reet furn & iture & \\
\hline$X_{1 \cdot 3}$ & $=$ Mate & permu & kaan & $X_{1.6}$ & $=V \epsilon$ & getasi & & \\
\hline
\end{tabular}

Tabel 4. Interpretasi kenyamanan fisik $\left(\mathrm{X}_{1}\right)$

\begin{tabular}{c|cc|c|c}
\hline No. & \multicolumn{2}{|c|}{ Korelasi } & Koefisien & Kesimpulan \\
\hline 1. & $\mathrm{Y}$ & dan $\mathrm{X}_{1.1}$ & 0,844 & Korelasi positif \\
\hline 2. & $\mathrm{Y}$ & dan $\mathrm{X}_{1.2}$ & 0,107 & Korelasi positif \\
\hline 3. & $\mathrm{Y}$ & dan $\mathrm{X}_{1.3}$ & 0,002 & Korelasi positif \\
\hline 4. & $\mathrm{Y}$ & dan $\mathrm{X}_{1.4}$ & $-0,217$ & Korelasi negatif \\
\hline 5. & $\mathrm{Y}$ & dan $\mathrm{X}_{1.5}$ & $-0,070$ & Korelasi negatif \\
\hline 6. & $\mathrm{Y}$ & dan $\mathrm{X}_{1.6}$ & $-0,005$ & Korelasi negatif \\
\hline
\end{tabular}

\begin{tabular}{c|cc|c|c|c}
\hline No. & \multicolumn{2}{|c|}{ Korelasi } & Sig. & Keterangan & Kesimpulan \\
\hline 1. & $\mathrm{Y}$ & dan $\mathrm{X}_{1.1}$ & 0.000 & Signifikan & Ha Diterima \\
\hline 2. & $\mathrm{Y}$ & dan $\mathrm{X}_{1.2}$ & 0.180 & Tidak signifikan & $\mathrm{H}_{\circ}$ Ditolak \\
\hline 3. & $\mathrm{Y}$ & dan $\mathrm{X}_{1.3}$ & 0.494 & Tidak signifikan & $\mathrm{H}_{\circ}$ Ditolak \\
\hline 4. & $\mathrm{Y}$ & dan $\mathrm{X}_{1.4}$ & 0.031 & Signifikan & Ha Diterima \\
\hline 5. & $\mathrm{Y}$ & dan $\mathrm{X}_{1.5}$ & 0.276 & Tidak signifikan & $\mathrm{H}_{\circ}$ Ditolak \\
\hline 6. & $\mathrm{Y}$ & dan $\mathrm{X}_{1.6}$ & 0.482 & Tidak signifikan & $\mathrm{H}_{\circ}$ Ditolak \\
\hline
\end{tabular}

2. Interpretasi kenyamanan spasial-visual $\left(\mathrm{X}_{2}\right)$

Pada setiap indikator diantaranya: korelasi positif yang terkait dengan tingkat kenyamanan sebanyak 3 indikator dan korelasi negatif sebanyak 3 indikator. Dari hasil output kenyamanan spasial-visual menunjukkan bahwa semua indikator yang terdapat pada kenyamanan spasial-visual, tidak ada yang saling berhubungan, karena tingkat Sig-nya lebih besar dari $(0,05)$. Sehingga dari hasil analisis disimpulkan bahwa kenyamanan spasial-visual tidak mempengaruhi tingkat kenyamanan jalur pedestrian pada kawasan CBD Kota Makassar. 


\section{Rohana, Analisis Pemanfaatan Jalur Pedestrian}

Tabel 5. Hasil uji regresi sederhana kenyamanan spasial-visual $\left(\mathrm{X}_{2}\right)$

\begin{tabular}{|c|c|c|c|c|c|c|c|c|c|}
\hline & & & & Model Suu & ary & & & & \\
\hline \multirow[b]{2}{*}{ Model } & \multirow[b]{2}{*}{$\mathrm{R}$} & \multirow[b]{2}{*}{$\begin{array}{c}\mathrm{R} \\
\text { Square }\end{array}$} & \multirow{2}{*}{$\begin{array}{c}\text { Adjusted R } \\
\text { Square }\end{array}$} & \multirow{2}{*}{$\begin{array}{l}\text { Std. Error of } \\
\text { the Estimate }\end{array}$} & \multicolumn{5}{|c|}{ Change Statistics } \\
\hline & & & & & $\begin{array}{l}\text { R Square } \\
\text { Change }\end{array}$ & \begin{tabular}{c|}
$\mathrm{F}$ \\
Change
\end{tabular} & df1 & df 2 & $\begin{array}{c}\text { Sig. F } \\
\text { Change }\end{array}$ \\
\hline 1 & $.096^{2}$ & .009 & -.078 & 893 & .009 & .106 & 6 & 68 & .995 \\
\hline
\end{tabular}

Tabel 6. Hasil uji korelasi kenyamanan spasial-visual $\left(\mathrm{X}_{2}\right)$

\begin{tabular}{ll|r|r|r|r}
\multicolumn{7}{|c|}{ Correlations } \\
\hline & & \multicolumn{1}{c|}{$\mathrm{Y}$} & \multicolumn{1}{c|}{ X2.1 } & \multicolumn{1}{c}{ X2.2 } & \multicolumn{1}{c}{ X2.3 } \\
\hline Pearson & $\mathrm{Y}$ & 1.000 & -.064 & -.040 & -.011 \\
Correlation & $\mathrm{X} 2.1$ & -.064 & 1.000 & -.037 & -.043 \\
& $\mathrm{X} 2.2$ & -.040 & -.037 & 1.000 & .014 \\
& $\mathrm{X} 2.3$ & -.011 & -.043 & .014 & 1.000 \\
\hline Sig. (1-tailed) & $\mathrm{Y}$ & & .293 & .366 & .463 \\
& $\mathrm{X} 2.1$ & .293 & & .377 & .357 \\
& $\mathrm{X} 2.2$ & .366 & .377 & & .452 \\
& $\mathrm{X} 2.3$ & .463 & .357 & .452 & \\
\hline $\mathrm{N}$ & $\mathrm{Y}$ & 75 & 75 & 75 & 75 \\
& $\mathrm{X} 2.1$ & 75 & 75 & 75 & 75 \\
& $\mathrm{X} 2.2$ & 75 & 75 & 75 & 75 \\
& $\mathrm{X} 2.3$ & 75 & 75 & 75 & 75 \\
\hline
\end{tabular}

$$
\begin{gathered}
\mathrm{X}_{2^{-}}=\text {Entrance Bangunan } \\
\mathrm{X}_{2^{-2}}=\text { Signage Bangunan } \\
\mathrm{X}_{2^{-3}}=\text { Tinggi Bangunan }
\end{gathered}
$$

Tabel 7. Interpretasi kenyamanan spasial-visual $\left(\mathrm{X}_{2}\right)$

\begin{tabular}{c|cc|c|c}
\hline No. & \multicolumn{2}{|c|}{ Korelasi } & Koefisien & Kesimpulan \\
\hline 1. & $\mathrm{Y}$ & dan $\mathrm{X}_{2.1}$ & -.064 & Korelasi negatif \\
\hline 2. & $\mathrm{Y}$ & dan $\mathrm{X}_{2.2}$ & -.040 & Korelasi negatif \\
\hline 3. & $\mathrm{Y}$ & dan $\mathrm{X}_{2.3}$ & -.011 & Korelasi negatif \\
\hline
\end{tabular}

\begin{tabular}{c|cc|c|c|c}
\hline No. & \multicolumn{2}{|c|}{ Korelasi } & Sig. & Keterangan & Kesimpulan \\
\hline 1. & $\mathrm{Y}$ & dan $\mathrm{X}_{2.1}$ & .293 & Tidak signifikan & $\mathrm{H}_{\circ}$ Ditolak \\
\hline 2. & $\mathrm{Y}$ & dan $\mathrm{X}_{2.2}$ & .366 & Tidak signifikan & $\mathrm{H}_{\circ}$ Ditolak \\
\hline 3. & $\mathrm{Y}$ & dan $\mathrm{X}_{2.3}$ & .463 & Tidak signifikan & $\mathrm{H}_{\circ}$ Ditolak \\
\hline
\end{tabular}

3. Interpretasi kenyamanan non-fisik

Pada setiap indikator menunjukkan korelasi negatif terhadap tingkat kenyamanan. Dan hasil output kenyamanan non-fisik adalah semua indikator yang terdapat pada variabel kenyamanan non-fisik tidak ada yang saling berhubungan, karena nilai tingkat Sig-nya lebih besar dari $(0,05)$. Sehingga dari hasil analisis disimpulkan bahwa kenyamanan non-fisik tidak mempengaruhi tingkat kenyamanan jalur pedestrian pada kawasan CBD Kota Makassar. 
Tabel 8. Hasil uji regresi sederhana kenyamanan non fisik $\left(\mathrm{X}_{3}\right)$

\begin{tabular}{l|l|l|r|r|r|r|r|r|r}
\hline Model & $\mathrm{R}$ & R Square & $\begin{array}{c}\text { Adjusted R } \\
\text { Square }\end{array}$ & $\begin{array}{c}\text { Std. Error } \\
\text { of the } \\
\text { Estimate }\end{array}$ & $\begin{array}{c}\text { R Square } \\
\text { Change }\end{array}$ & $\begin{array}{c}\text { F } \\
\text { Change }\end{array}$ & df1 & df2 & $\begin{array}{c}\text { Sig. F } \\
\text { Change }\end{array}$ \\
\hline 1 & $.324^{4}$ & .105 & .054 & .799 & .105 & 2.057 & 4 & 70 & .096 \\
\hline
\end{tabular}

\begin{tabular}{|c|c|c|c|c|c|c|}
\hline \multicolumn{7}{|c|}{ Correlations } \\
\hline & & $\mathrm{X} 3.1$ & $\mathrm{X} 3.2$ & $\mathrm{X} 3.3$ & $\mathrm{X} 3.4$ & $\mathrm{Y}$ \\
\hline \multirow[t]{3}{*}{$\mathrm{X} 3.1$} & Pearson Correlation & 1 & -.048 & $.237^{\circ}$ & -.003 & .115 \\
\hline & Sig. (2-tailed) & & .682 & .041 & .982 & .325 \\
\hline & $\mathrm{N}$ & 75 & 75 & 75 & 75 & 75 \\
\hline \multirow[t]{3}{*}{$\mathrm{X} 3.2$} & Pearson Correlation & -.048 & 1 & .017 & .008 & -.170 \\
\hline & Sig. (2-tailed) & .682 & & .887 & .943 & .144 \\
\hline & $\mathrm{N}$ & 75 & 75 & 75 & 75 & 75 \\
\hline \multirow[t]{3}{*}{$\mathrm{X} 3.3$} & Pearson Correlation & $.237^{\circ}$ & .017 & 1 & -.092 & -.206 \\
\hline & Sig. (2-tailed) & .041 & .887 & & .431 & .076 \\
\hline & $\mathrm{N}$ & 75 & 75 & 75 & 75 & 75 \\
\hline \multirow[t]{3}{*}{$\mathrm{X} 3.4$} & Pearson Correlation & -.003 & .008 & -.092 & 1 & .116 \\
\hline & Sig. (2-tailed) & .982 & .943 & .431 & & .323 \\
\hline & $\mathrm{N}$ & 75 & 75 & 75 & 75 & 75 \\
\hline \multirow[t]{3}{*}{$\mathrm{Y}$} & Pearson Correlation & .115 & -.170 & -.206 & .116 & 1 \\
\hline & Sig. (2-tailed) & .325 & .144 & .076 & .323 & \\
\hline & $\mathrm{N}$ & 75 & 75 & 75 & 75 & 75 \\
\hline \multicolumn{7}{|c|}{ Correlation is significant at the 0.05 level (2-tailed). } \\
\hline \multirow{2}{*}{$\begin{array}{l}X_{3} . \\
X_{3} .\end{array}$} & $=$ Keamanan & & $X_{3 \cdot 3}=$ & Keberac & an PKL & \\
\hline & $=$ Panas dan $\mathrm{h}$ & & $X_{3.4}$ & Traffic c & ndition & \\
\hline
\end{tabular}

Tabel 9. Interpretasi kenyamanan non fisik $\left(\mathrm{X}_{3}\right)$

\begin{tabular}{c|cc|c|c}
\hline No. & \multicolumn{2}{|c|}{ Korelasi } & Koefisien & Kesimpulan \\
\hline 1. & Y & dan $\mathrm{X}_{3.1}$ & 0,115 & Korelasi positif \\
\hline 2. & $\mathrm{Y}$ & dan $\mathrm{X}_{3.2}$ & $-0,170$ & Korelasi negatif \\
\hline 3. & $\mathrm{Y}$ & dan $\mathrm{X}_{3.3}$ & $-0,206$ & Korelasi negatif \\
\hline 4. & $\mathrm{Y}$ & dan $\mathrm{X}_{3.4}$ & $-0,116$ & Korelasi negatif \\
\hline
\end{tabular}

\begin{tabular}{c|cc|c|c|c}
\hline No. & \multicolumn{2}{|c|}{ Korelasi } & Sig. & Keterangan & Kesimpulan \\
\hline 1. & $\mathrm{Y}$ & dan $\mathrm{X}_{3.1}$ & 0,325 & Tidak signifikan & $\mathrm{H}_{\circ}$ Ditolak \\
\hline 2. & $\mathrm{Y}$ & dan $\mathrm{X}_{3.2}$ & 0,144 & Tidak signifikan & $\mathrm{H}_{\circ}$ Ditolak \\
\hline 3. & $\mathrm{Y}$ & dan $\mathrm{X}_{3.3}$ & 0,076 & Tidak signifikan & $\mathrm{H}_{\circ}$ Ditolak \\
\hline 4. & $\mathrm{Y}$ & dan $\mathrm{X}_{3.4}$ & 0,323 & Tidak signifikan & $\mathrm{H}_{\circ}$ Ditolak \\
\hline
\end{tabular}

\section{Pengaruh Karakteristik Pengguna Jalur Pedestrian terhadap Tingkat Kenyamanan}

Untuk mengetahui pengaruh karakteristik pengguna jalur pedestrian terhadap tingkat kenyamanan, maka dapat dilihat pada tingkat signifikansi uji korelasi dan regresi sederhana.

Dari nilai signifikansi hasil uji regresi sederhana diketahui bahwa kenyamanan fisik $\left(\mathrm{X}_{1}\right)$ sangat mempengaruhi tingkat kenyamanan $(\mathrm{Y})$. Hal ini bisa dilihat pada hasil output $\mathrm{R}=0,853$ yang menandakan hubungan yang sangat kuat dalam mempengaruhi tingkat kenyamanan. Dan kenyamanan spasial-visual $\left(\mathrm{X}_{2}\right)$ dan kenyamanan non-fisik $\left(\mathrm{X}_{3}\right)$ secara simultan tidak menunjukkan nilai yang signifikan, tetapi nilai korelasi yang ditampilkan pada hasil output SPSS 


\section{Rohana, Analisis Pemanfaatan Jalur Pedestrian}

menunjukkan adanya korelasi antara kenyamanan spasial-visual dan kenyamanan non-fisik terhadap tingkat kenyamanan.

Setelah didapatkan hasil berupa angka-angka, maka di buat Konsep Penerapan Walkability berbasis lingkungan berdasarkan dari hasil analisis. (Gambar 3.)

\section{Pembahasan}

Dalam penelitian ini terlihat, ada beberapa pendapat responden menyatakan bahwa lebar jalur yang ada saat ini termasuk kurang nyaman, hal ini dimaksudkan karena banyaknya bangunan-bangunan yang mengalami peninggian pada bagian entrance, sehingga jalur untuk berjalan jadi berkurang. Sedangkan pendapat peneliti menyatakan bahwa ruang yang ada saat ini sudah cukup nyaman bila ditinjau dari segi perhitungan level of service (LOS). Karena dari hasil perhitungan dan pengukuran di lapangan, didapatkan kapasitas ruang yang termasuk dalam kategori LOS D, E dan F. Peneliti juga menganggap bahwa kepadatan pejalan kaki dengan ketersediaan ruang yang ada saat ini, sudah bisa mengakomodir para pedestrian untuk berjalan di sepanjang jalur pedestrian yang tersedia pada kawasan tersebut.

Komponen Fasad mengekspresikan berbagai aspek yang muncul dan dapat diamati secara visual. Dalam konteks arsitektur kota, fasad bangunan tidak hanya bersifat dua dimensi saja akan tetapi bersifat tiga dimensi yang dapat merepresentasikan masing-masing bangunan tersebut dalam kepentingan publik (kota) atau sebaliknya, Krier (1983) dalam Riany (2013).

Menurut Anggriani (2009), Kenyamanan (comfort) merupakan segala sesuatu yang memperlihatkan kesesuaian dirinya dan harmonis dengan penggunaan suatu ruang. Jalur pedestrian memiliki peran penting dalam pembentukan arsitektur kota. Kondisi jalur pedestrian yang mengutamakan kenyamanan, tentunya juga mempertimbangkan aspek manusiawi.

Carr et.al dalam Carmona dkk (2003), jalur pedestrian sebagai ruang publik dalam suatu kota akan berperan baik jika mengandung unsur antara lain comfort (kenyamanan) yang dipengaruhi oleh environment comfort yang berupa perlindungan dari pengaruh alam seperti sinar matahari, angin; physical comfort yang berupa ketersediaan fasilitas penunjang yang cukup; social dan psychological comfort berupa kondisi sehat dan tenang.

Ovstedal (2009) dikutip dari Rohana (2016), kenyamanan bagi pejalan kaki adalah reaksi emosional yang positif dalam suatu lingkungan yang mencakup reaksi fisiologis, fisik, sosial dan psikologis.

Menurut Shirvani (1985), kenyamanan merupakan salah satu kriteria desain tak terukur dalam kualitas lingkungan kota, selain pencapaian, kecocokan, pemandangan, identitas dan rasa, kenyamanan juga bisa dicapai dengan melakukan pelebaran trotoar sesuai dengan kebutuhan.

Khisty (2003) dalam Gumelar (2011), faktor-faktor yang harus dipertimbangkan dalam merancang fasilitas pejalan kaki, antara lain: faktor kenyamanan (comfort), faktor kemudahan (convenience), faktor keselamatan (safety).

Fruin (1979) menyatakan bahwa elemen yang ada pada trotoar, seperti kotak pos, telepon umum, tempat sampah dan elemen fungsional lain seperti rambu lalu lintas, hydrant, dapat dirancang sedemikian sehingga tidak mengganggu alur pejalan kaki. Trotoar dan ramp sebagai pembeda ketinggian juga dapat memberikan kenyamanan bagi tuna grahita (handicapped) atau pedestrian dengan kereta bayi. Kenyamanan juga meliputi seluruh elemen pedestrian termasuk halte bus, arcade mall, bangku kota, alur pedestrian dan akses ke bangunan di sekitarnya, entrance ketempat umum, parkiran atau konektivitas dengan sistem transportasi kota.

Selain dari pepohonan, Gehl (1987) mengungkapkan bahwa pedestrian cukup sensitif dengan kondisi permukaan jalan. Jalan yang berpasir, berbatu, tidak rata akan mengganggu. Demikian juga dengan kondisi jalan yang licin dan basah. Kondisi-kondisi tersebut akan mengganggu pedestrian, terutama mereka mempunyai keterbatasan fisik. 
Untuk mendukung suatu lingkungan agar menjadi kawasan yang berorientasi pejalan kaki dengan memperhatikan aspek keamanan dan kenyamanan, keterhubungan jalur serta menawarkan visual yang menarik untuk menambah minat perjalanan dibutuhkan: konektivitas yaitu terintegrasinya jalur pedestrian secara utuh, aksesibilitas yaitu ketersediaan jalur yang lebar serta kualitas permukaanKeamanan, ketersediaan tempat penyeberangan dan pencahayaan kenyamanan (Hutabarat, 2011).

Konsep penerapan walkable city mungkin belum banyak diketahui banyak orang, namun dapat ditelaah dari pengertian itu sendiri. Walkable city adalah suatu konsep perancangan kota yang didukung oleh perencanaan transportasi yang memungkinkan warganya untuk berjalan kaki dalam melakukan kegiatan kesehariannya.

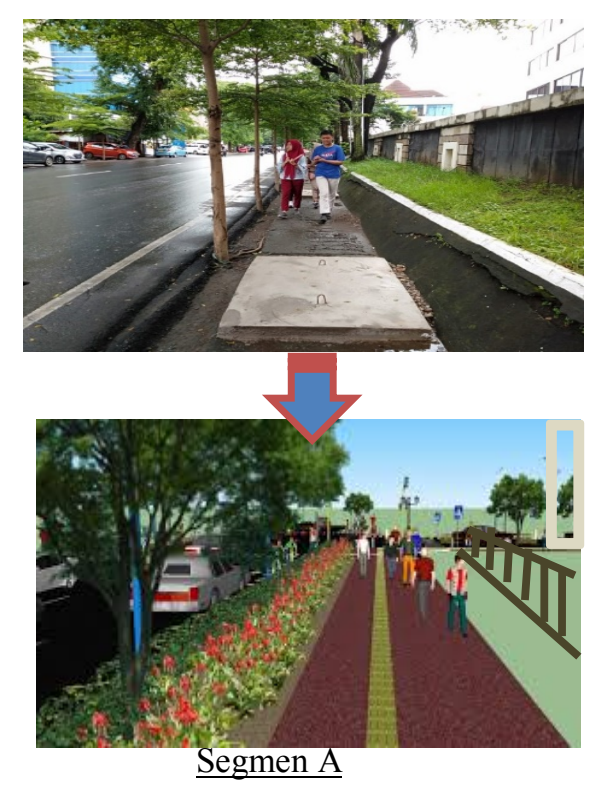

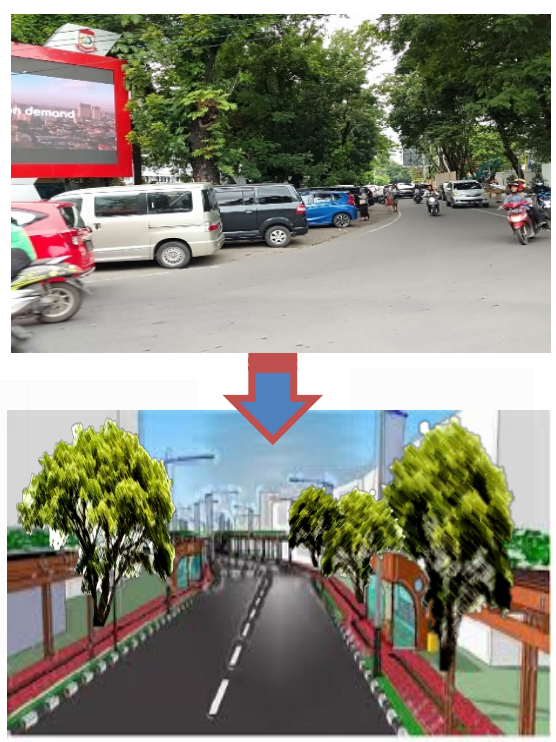

Segmen B 

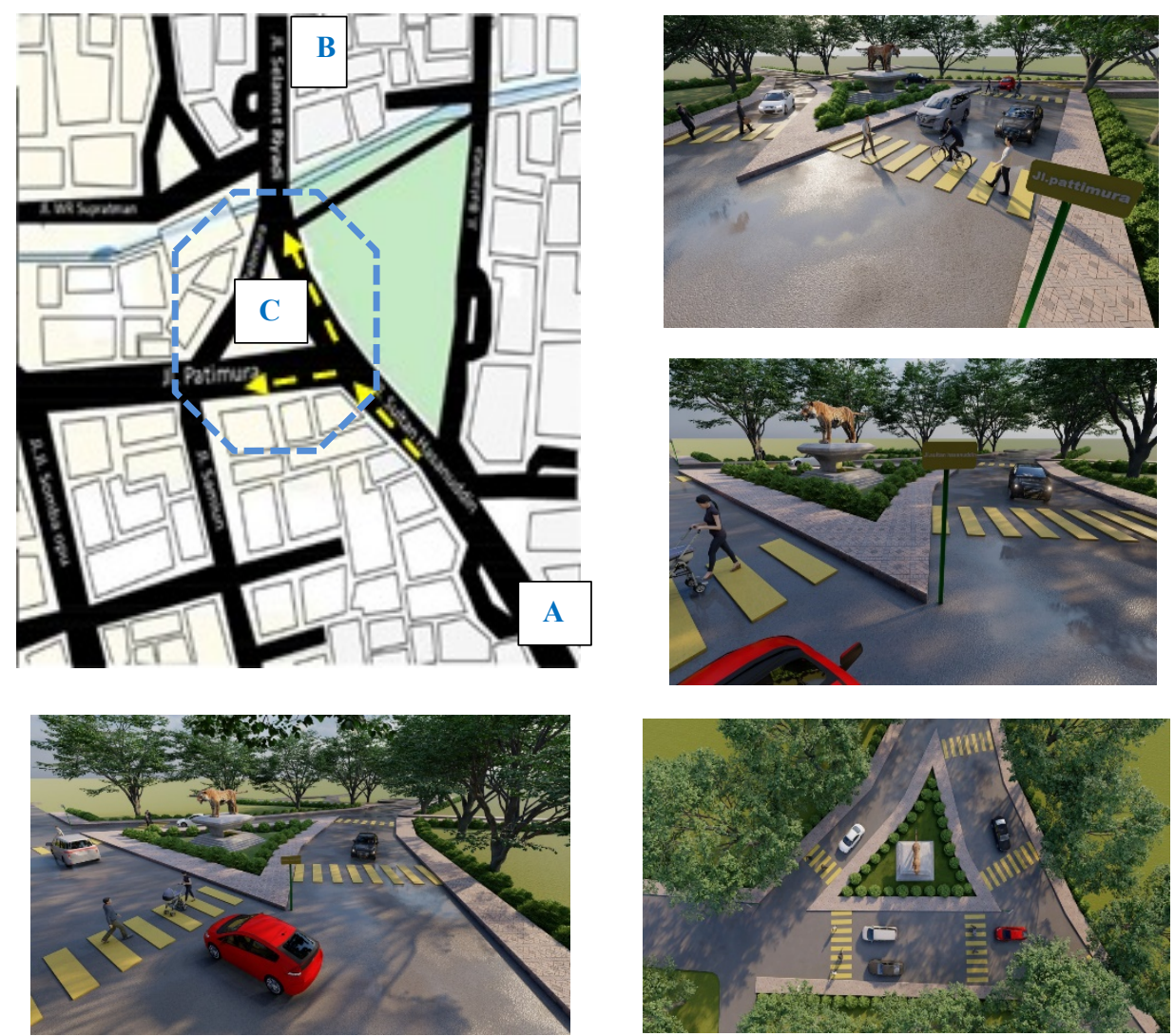

$\underline{\text { Segmen C }}$

Gambar 3. Konsep Penerapan Walkability

\section{Simpulan dan Saran}

\section{Simpulan}

Berdasarkan penelitian dan hasil analisis maka disimpulkan bahwa tingkat kenyamanan jalur pedestrian berdasarkan persepsi pengguna ditinjau dari aspek kenyamanan fisik $\left(\mathrm{X}_{1}\right)$ : semua indikatornya termasuk kategori kurang nyaman. Kenyamanan spasial-visual $\left(\mathrm{X}_{2}\right)$ : entrance bangunan termasuk kategori kurang nyaman, untuk signage/penanda dan tinggi bangunan masuk dalam kategori nyaman. Kenyamanan non-fisik $\left(\mathrm{X}_{3}\right)$ : keamanan, keberadaan PKL dan kondisi lalu lintas termasuk kategori kurang nyaman dan (panas dan hujan) dikategorikan nyaman. Elemen-elemen arsitektur yang berhubungan/terkait dengan tingkat kenyamanan pada ketiga variabel yaitu kenyamanan fisik, kenyamanan spasial-visual, dan kenyamanan non-fisik secara simultan mempunyai hubungan dengan tingkat kenyamanan, meskipun tingkat hubungannya ada yang kuat dan ada yang lemah. Hal ini menunjukkan bahwa semua elemen secara bersama-sama menentukan kenyamanan jalur pedestrian.

\section{Saran}

Saran yang disumbangkan dari hasil penelitian ini adalah:

1. Perlunya penataan kembali yang sistematis untuk penyediaan fasilitas pejalan kaki yang memperhatikan aspek kenyamanan baik fisik, spasial-visual dan non-fisik. 
2. Penanganan jalur pedestrian pada kawasan CBD, sebaiknya memperhatikan skala prioritas berdasarkan hasil uji analisis dengan tingkat signifikansi yang paling dominan.

3. Perancangan jalur pedestrian sebaiknya mengacu pada standar teknis Pedoman Penyediaan Fasilitas Pejalan Kaki pada Ruang Perkotaan dengan mempertimbangkan lahan yang tersedia, dan volume pejalan kaki serta fungsi kawasan sehingga pemanfaatannnya bisa lebih efektif.

4. Perancangan jalur pedestrian sebaiknya mengakomodir semua kebutuhan pengguna termasuk kaum difabel/penyandang cacat.

5. Perlu adanya penelitian lanjutan mengenai tingkat kenyamanan pedestrian berdasarkan tipologi pejalan kaki.

6. Bagi pemerintah dan pihak yang terkait, sebaiknya melakukan revitalisasi terhadap jalur pedestrian di lokasi penelitian, karena terintegrasi dengan Kawasan CBD.

\section{Referensi}

Anggriani, Niniek. (2009). Pedestrian Ways dalam perancangan kota, Penerbit Yayasan Humaniora, Klaten.

Arikunto, Suharsimi. (2010). Prosedur penelitian: Suatu pendekatan praktek. Jakarta: Rineka Cipta.

Carmona. dkk. (2003). Public Space Urban Space: The Didimension of Urban Design, London, Architectural Press.

Gumelar T, Rendy. (2011). Studi Evaluasi Pelayanan Pedestrian Jalan Urip Sumoharjo Panglima Sudirman Surabaya. Tugas Akhir Program Studi Teknik Sipil, Fakultas Teknik Sipil dan Perencanaan Universitas Pembangunan Nasional "Veteran" Jawa Timur 2011

Hutabarat, Ria Sulinda. (2011). Walkability Planning in Jakarta. University of California, Berkeley.

Mulwan, Afiat. (2011). Pedestrianisasi Kawasan Perdagangan Somba Opu (Tinjauan terhadap manajemen pengalihan lalu lintas), Program Pasca Sarjana Teknik Perencanaan Transportasi Universitas Hasanuddin, Makassar

Riany, Meta. (2013). Kajian Ekspresi Bangunan Eiger Adventure Store Jl. Sumatera Bandung ditinjau dari Ekterior dan Interior Bangunan. Jurnal Reka Karsa (Jurnal Online Institut Teknologi Nasional).

Rohana. (2016). Tingkat Kenyamanan Ruang Pedestrian pada Jalur Wisata Perbelanjaan Jalan SombaOpu Makassar. Jurnal Multek, Kopertis Wilayah IX, Vol. 2 No. 2.

Sugiyono. (2003). Metode Penelitian Administrasi. Bandung : ALFABETA. 